\title{
負荷による重心動摇分析
}

$\begin{array}{llll}\text { 雲 } \text { 健 雄・森 } & \text { 裕 司 } \\ \text { 涌谷治 夫・町塚博文 }\end{array}$

\section{Analysis of Stabilograms Recorded during Equilibrium Challenges}

\author{
Takeo Kumoi, Hiroshi Mori, Haruo Wakutani \\ and Hirofumi Machizuka
}

(Hyogo Medical College)

We analysed the stabilograms of subjects standing still, on a rolling platform, or with impulse stimulation. These challenges test the postural restoration reflex system which the usual stabilogram at rest cannot do. We conclude that this method is helpful in the diagnosis of vertigo.

Key words : stabilogram, rolling stimulation, impulse stimulation

緒言

重心動摇検査法は，その実施が簡便でかつ患者への負担も少ない検查法として注目を浴びてきた. 本検査法の特長は患者の重心動摇を数量的に把握できることである．今日迄の本検査法を用いての 分析は, 主として被検者の安静直立時の重心動摇の大きさ ${ }^{1) ~-5)}$, 面積6) 14), 軌跡距離 ${ }^{3(4)(6) 9) 15) ~ 20), ~}$

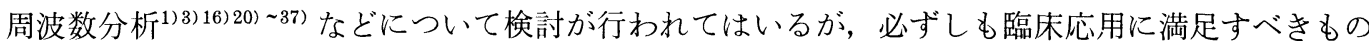
とはいえない，今回著者らは，安静時の自発性の重心動摇を分析するだけでなく，ある種の負荷を 加えた時の応答としての重心動摇を分析する方法を試みた。この負荷を加える方法は，安静時の重 心動摇の検討のみでは検出できなかった立ち直り反射系の状態を把握できる可能性があり，眩暈症 患者の病巣診断の一助になると考光，1）ローリング負荷，2）撃振による負荷，を用いた重心動 摇検查法について研究を行った.

方法

実験 1：ローリング負荷

被検者にローリング負荷を加えるために，前 後軸を中心として左右へ正弦波周期でシーソー 状の 往復傾斜運動する電動傾斜台を作製 した (永島医科器械製)。この試作台で傾斜範囲を左 右へ $2.5^{\circ}$ の負荷角度に設定し, 周波数は 0 , $0.05, \quad 0.075,0.1,0.15,0.2,0.3,0.4$, $0.5 \mathrm{~Hz}$ について負荷を加えた。この台上に重 心動摇計を設置し，被検者の左右への重心動摇
と，台の傾斜角度とをデータレコーダーに同時 記録した（図 1 ）。

被検者は重心動摇計の中心上に閉眼で起立さ せ，足位は原則として閉足位としたが，負荷の 増強に伴って多少の開足を認めてもあえて強制 はしなかった。

被検対象は正常対象群 100 名, 前庭障害群 15 名，中枢障害群12名とした，疾患群は，当科外 来を受診した眩莗患者症例の中で，前庭障害群 


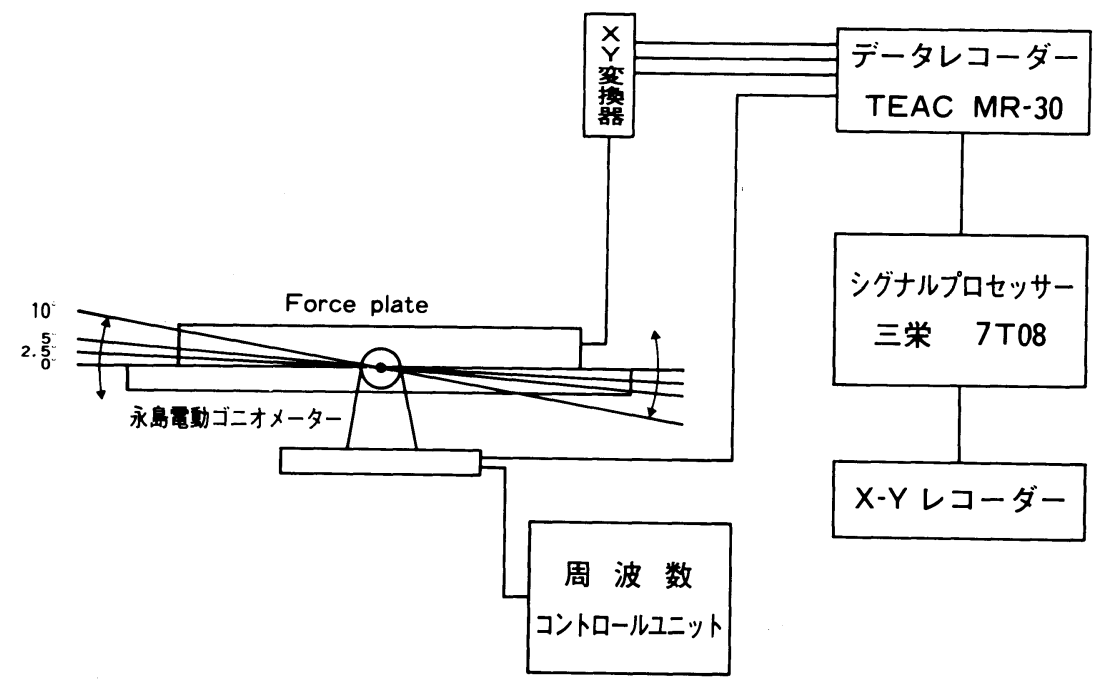

図 1 検査システム（ローリング負荷 $)$

表 1 ローリング負荷による検討対象

正 常 群

100名

前庭障害群

$x= \pm ー ル$ 病

11名

突 発 性 難 聴

4名

中枢障害群

椎骨脳底動脈不全

11名

左小脳腫瘍

1 名

表 2 撃振負荷による検討対象

正 常 群

23名

前庭障害群

$x=エ ー ル$ 病

4名

突 発性 難 聴

4名

ハント症候群

1名

中权障害群

椎骨脳底動脈不全

13名

脳梗塞

2名

脳挫傷

2名

起立性低血圧

1名

小脳失 調

1名

脳腫瘍術後

1名

アルコール脑症
にはメニェール病と突発性難聴とで, 中枢障害 所見のみられない純前庭性のもののみを組み入 れ, 中枢障害群には眼振検査や視運動性眼振検 査などで明らかな中枢障害所見を示すものを組 み入れた（椎骨脳底動脈循環不全11例, 小脳腫 瘍 1 例). 両群ともに閉眼起立可能な症例の及 を対象として検査を行った（表 1 ）.

実験 2 : 撃振による負荷

重心動摇計上に閉眼で直立させた被検者の腰 部に左右方向への瞬間的衝撃力を与え得る簡易 な装置を作製し，その衝撃瞬間から以後 10 秒間 の左右方向への重心動摇を記録した（図 2 ). 10 回加算を行ったものを電算機で on-line に処理 してさらに摇れの減衰係数をも算出した.

被検対象は正常対象群 23 名, 前庭障害群 9 名, 中枢障害群 21 名を対象とした（表 2 ）。疾 患群は, 実験 1 と同様に前庭障害群はメニエー ル病とカロリックテストで 1 側の CP が確認 された突発性難聴及びハント症候群症例で, 中 枢障害群は DSA (Digital Subtraction Angsography）で椎骨脳底動脈の閉塞や狭窄が認め られるような椎骨脳底動脈循環不全を中心とし た純中枢障害所見を示す者のみを組及入れた (表 2 ). 
結

実験 1：ローリング負荷

周波数分析に際しては, 疾患群では重心動摇 の増大に伴ら高い周波数成分の出現を予想して サンプリングタイムを $40 \mathrm{mec}$ に設定し，また 2 回加算によって計 81.9 秒間の分析を行った (これによって最高 $12.5 \mathrm{~Hz}$ までの周波数の分 析が可能となる). また疾患群では高い周波数帯 に飛びはなれてパワーが出現することがあり, これらの成分をも含めてパワー成分の完全に消 失する点をパワーの上限とすることとした.

正常群でのパワー上限の平均值は, 無負荷時 には $3.37 \mathrm{~Hz}$ を示し, 負荷 $0.05 \mathrm{~Hz}$ では 4.97 $\mathrm{Hz}$, 負荷 $0.075 \mathrm{~Hz}$ では $5.30 \mathrm{~Hz}$, 負荷 $0.1 \mathrm{~Hz}$ で は5.67 Hz，負荷 $0.15 \mathrm{~Hz}$ では6.00 Hz となり これ以上の負荷周波数では $5.8 \mathrm{~Hz}$ 程度に一定 する。前庭障害群では, パワー上限は無負荷時 平均 $3.22 \mathrm{~Hz}$, 負荷 $0.05 \mathrm{~Hz}$ では $4.74 \mathrm{~Hz}$, 負荷 $0.1 \mathrm{~Hz}$ では $4.96 \mathrm{~Hz}$, 負荷 $0.2 \mathrm{~Hz}$ 以上では 6 $\mathrm{Hz}$ 程度となった. 負荷 $0.4,0.5 \mathrm{~Hz}$ では正常 群に比べてやや大きい傾向 $(\mathrm{p}<0.05)$ を示し たが，それ以外の周波数負荷では正常群との間 に有意の差を認め得なかった。

他方, 中枢障害群では無負荷時のパワー上限 は平均 $4.70 \mathrm{~Hz}$ を示し, これは $5 \%$ 以下の危険

\section{果}

率で正常群及び前庭障害群と比較検討して有意 に高いと判定された。また負荷 $0.05 \mathrm{~Hz}$ では $6.96 \mathrm{~Hz}$ を示しこれもまた $1 \%$ 以下の危険率で 正常群及び前庭障害群と対比して有意に高い值 を示した．負荷 $0.075 \mathrm{~Hz} \quad$ で $6.54 \mathrm{~Hz}$ ，負荷 0.1 $\mathrm{Hz}$ では6.87 Hz, 負荷 $0.2 \mathrm{~Hz}$ では $7.96 \mathrm{~Hz}$, の 值が得られ，いずれも同様に有意に高いと判定 される $(\mathrm{p}<0.01)$. 負荷 $0.3 \mathrm{~Hz}$ 以上では, 大 きい傾向（ $\mathrm{p}<0.05 ）$ の及が観察された（図 3 ).

相互相関分析を行ってみると, 正常群ではや はり, 負荷 $0.05 \mathrm{~Hz}$ では $1336 \mathrm{msec}$ の重心移動 の先行が認められ, 負荷 $0.075 \mathrm{~Hz}$ では $687 \mathrm{~ms}-$ ec, 負荷 $0.1 \mathrm{~Hz}$ では $173 \mathrm{msec}$, 負荷 $0.15 \mathrm{~Hz}$ で はー $83.8 \mathrm{msec}$ と次第に遅れを示すようになっ て以後約ー $100 \mathrm{msec}$ となって一定となる傾向 を示した（図4）.

前庭障害群では負荷 $0.1 \mathrm{~Hz}$ で重心移動の先 行が大きい $(\mathrm{p}<0.01)$ ことが認められたが, 正常群との平均値間の差は少なかった。 それ以 外では, 正常群との間に有意差は示さなから た.

中枢障害群では, 負荷 $0.05 \mathrm{~Hz}$ で $2316 \mathrm{msec}$ の明膫な重心移動の先行が認められた。これは

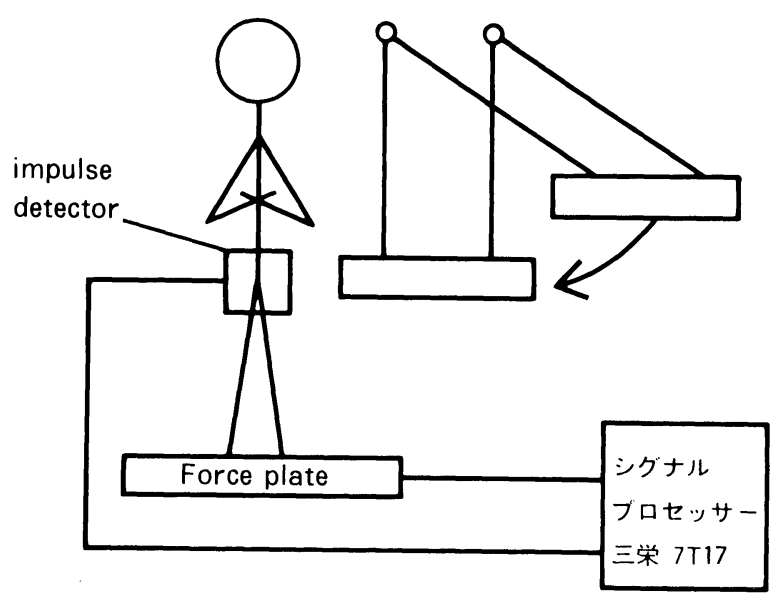

図 2 検査システム（撃振による負荷） 


\section{Upper limit of power (UL)}

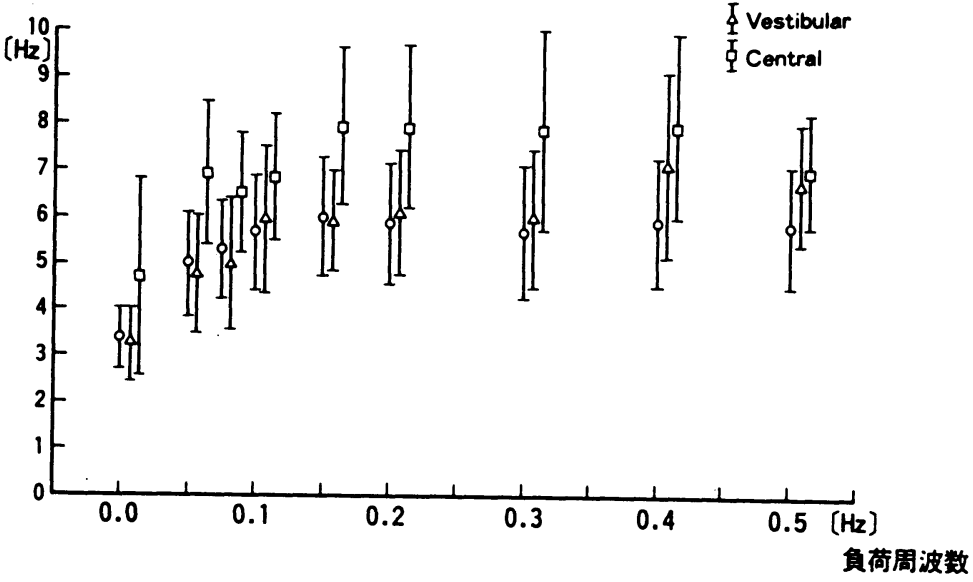

図 3 左右 $2.5^{\circ}$ 負荷時の各群のパワー上限の平均值と標準偏差

\section{Phase shift (PS)}

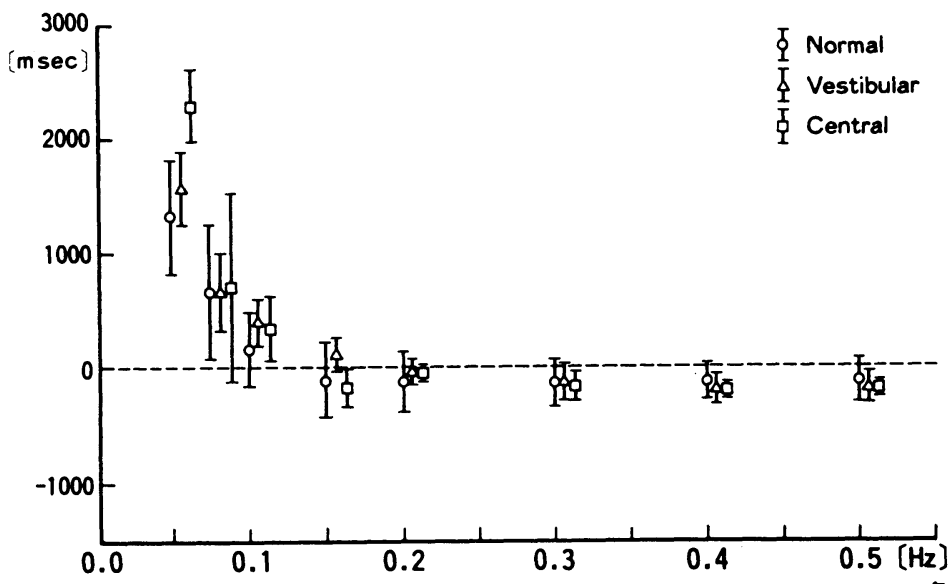

負荷周波数

図 4 左右 $2.5^{\circ}$ 負荷時の各群の位相差の平均値と標準偏差

危険率 $1 \%$ で正常群及び前庭障害群よりも有意 に大きい值であった．また負荷 $0.2 \mathrm{~Hz}$ で位相 の遅れが小さい以外は, 他の負荷周波数では有 意の変化は認められなかった.

実験 2 : 撃振による負荷

直立姿勢の被検者が瞬間的衝撃力を与えられ ると，まずその衝撃力の反対方向への大きい重
心の移動が起こり，その後次第に減衰してもと の直立安定位にもどる. 勿論人体の立ち直り反 射機構を簡単なモデルに置さかえることには多 少の疑問も残るがこの減衰振動運動を仮に単振 動のバネ運動にたとえると $\mathrm{Y}=\mathrm{Ae}^{-{ }^{-} t}$ の一般式 で表わすことができるであろら。この式では減 衰係数はんで示され，これはシグナルプロセッ 

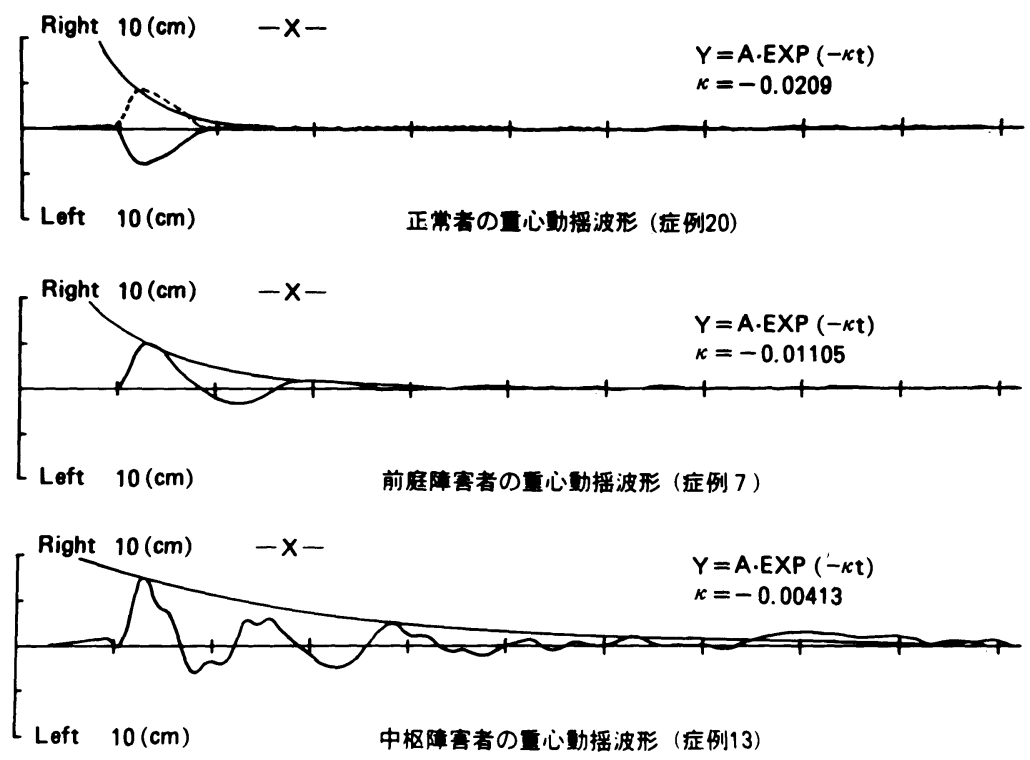

図 5 各群の重心動摇波形

\section{Damping coefficient}

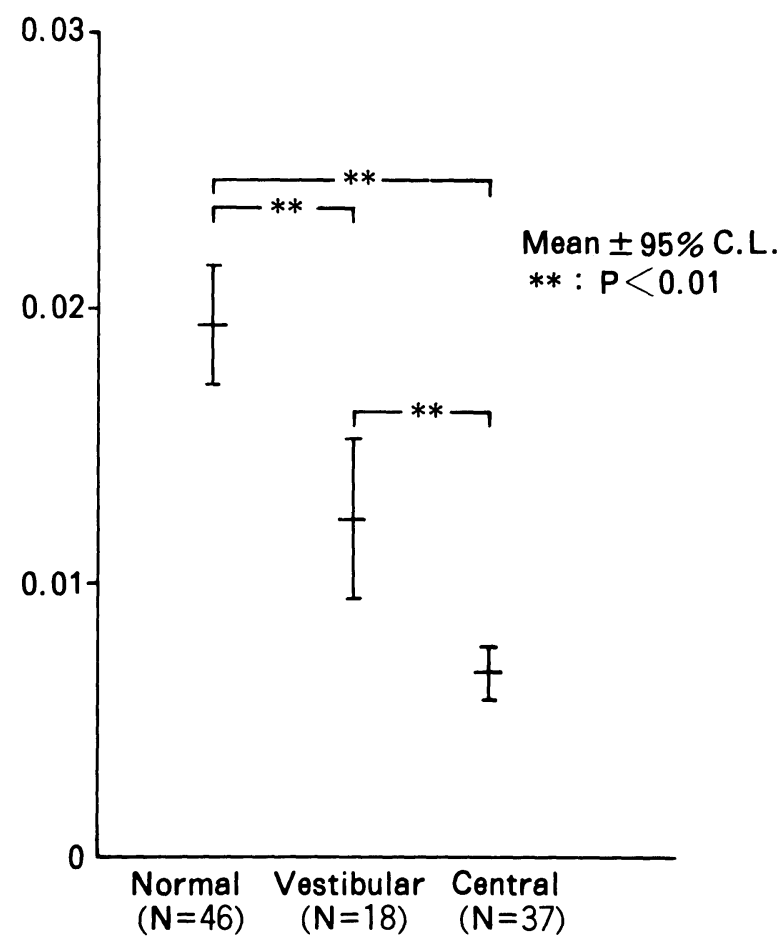

図 6 各群の減哀係数の平均值と標準偏差 
表 33 群の減衰係数

\begin{tabular}{|c|c|c|c|}
\hline 正 常 群 & & & \\
\hline 右 & 左 & & 平 均 \\
\hline $1: 0.0128$ & 0.02096 & & 0.01688 \\
\hline $2: 0.01532$ & 0.03419 & & 0.02476 \\
\hline $3: 0.02533$ & 0.03368 & & 0.02956 \\
\hline $4: 0.02193$ & 0.01772 & & 0.01958 \\
\hline $5: 0.01524$ & 0.03175 & & 0.02394 \\
\hline $6: 0.02608$ & 0.01759 & & 0.02184 \\
\hline $7: 0.01873$ & 0.0143 & & 0.01652 \\
\hline $8: 0.02464$ & 0.03047 & & 0.02756 \\
\hline $9: 0.0279$ & 0.01772 & & 0.02281 \\
\hline $10: 0.01724$ & 0.0364 & & 0.02682 \\
\hline $11: 0.02037$ & 0.02693 & & 0.02365 \\
\hline $12: 0.01594$ & 0.0198 & & 0.01787 \\
\hline $13: 0.01759$ & 0.01373 & & 0.01566 \\
\hline $14: 0.03441$ & 0.01411 & & 0.02426 \\
\hline $15: 0.00967$ & 0.01656 & & 0.01312 \\
\hline $16: 0.01377$ & 0.00938 & & 0.01158 \\
\hline $17: 0.01212$ & 0.03138 & & 0.02175 \\
\hline $18: 0.02449$ & 0.03682 & & 0.03066 \\
\hline $19: 0.0202$ & 0.047 & & 0.0336 \\
\hline $20: 0.02092$ & 0.02155 & & 0.02104 \\
\hline $21: 0.01432$ & 0.03053 & & 0.02243 \\
\hline $22: 0.0148$ & 0.02907 & & 0.02194 \\
\hline $23: 0.01143$ & 0.01039 & & 0.01091 \\
\hline \multicolumn{4}{|l|}{ 前庭障害群 } \\
\hline & 右 & 左 & 平均 \\
\hline $1:$ 左メ & 0.01039 & 0.01295 & 0.01167 \\
\hline $2:$ 右メ & 0.01354 & 0.00662 & 0.01008 \\
\hline $3:$ 右メ & 0.01106 & 0.0184 & 0.01473 \\
\hline $4:$ 左メ $=$ エール病 & 0.01049 & 0.01128 & 0.01089 \\
\hline 5 : 右突発性難聴 & 0.02308 & 0.02122 & 0.02215 \\
\hline 6 : 右突発性難聴 & 0.01368 & 0.00669 & 0.01019 \\
\hline 7 : 左突発性難聴 & 0.01182 & 0.01105 & 0.01144 \\
\hline 8 : 左突発性難聴 & 0.00728 & 0.00912 & 0.0082 \\
\hline
\end{tabular}

9 : ラムゼイハント症候群 0.009450 .005450 .0070

サー（三栄 7T17）によって on-line で簡単に 処理出来るので, 算出された減衰係数 $(\kappa)$ に ついて検討することとした.
中枢障害群

\begin{tabular}{llll}
\hline & 右 & 左 & 平 均 \\
$1:$ 椎骨脳底動脈不全 & 0.00618 & 0.0091 & 0.00764 \\
$2:$ 椎骨脳底動脈不全 & 0.00649 & 0.00279 & 0.00484 \\
$3:$ 椎骨脳底動脈不全 & 0.00728 & 0.00455 & 0.00592 \\
$4:$ 椎骨脳底動脈不全 & & 0.00427 & \\
$5:$ 椎骨脳底動脈不全 & & 0.00506 & \\
$6:$ 椎骨脳底動脈不全 & 0.00534 & 0.0092 & 0.00727 \\
$7:$ 椎骨脳底動脈不全 & 0.00549 & 0.01621 & 0.01085 \\
$8:$ 椎骨脳底動脈不全 & 0.00529 & & \\
$9:$ 椎骨脳底動脈不全 & 0.0101 & 0.00687 & 0.00849 \\
$10:$ 椎骨脳底動脈不全 & 0.00708 & 0.00615 & 0.00662 \\
$11:$ 椎骨脳底動脈不全 & 0.0048 & 0.00585 & 0.00497 \\
$12:$ 椎骨脳底動脈不全 & 0.00678 & 0.00374 & 0.00526 \\
$13:$ 椎骨脳底動脈不全 & 0.00488 & 0.00413 & 0.00451 \\
$14:$ 起立性低血圧 & 0.00495 & 0.0071 & 0.00663 \\
$15:$ 脳 梗 塞 & 0.00557 & 0.00767 & 0.00662 \\
$16:$ 脳 梗 塞 & 0.01226 & 0.00828 & 0.01027 \\
$17:$ 脳 挫 傷 & 0.00617 & 0.00639 & 0.00628 \\
$18:$ 脳 挫 傷 & 0.00938 & 0.01087 & 0.01013 \\
$19:$ 小脳失 調 & 0.00548 & 0.00413 & 0.0048 \\
$21:$ 脳腫瘍術後 & & 0.00229 & \\
21 ア ル ル脳症 & & 0.00168 &
\end{tabular}

on-line で処理された重心動摇波形は，正常 群では立ち直りは俊敏でかつ素早くもとの安定 位となるが，前庭障害群では波形の安定は少し 緩慢となる。中枢障害群ではこの傾向がより強 く出現して，もとの安定位にもどるのに時間を 要するとともに左右への 重心移動軌跡長も大 きく減衰能力が非常に弱いことを示している (図 5 ).

波形の右上に表示されている 数である.この係数を正常群, 前庭障害群, 中枢 障害群別にまとめたものが表 3 である．右と書 いてあるのは右側から左と記したのは左側から 刺激が加えられた場合の減衰係数である. 正常 群での減衰係数は一様に高くて特に左右の差も 認めないがやや左側からの刺激に対して高い傾 向を認めた。前庭障害群では一側 $\mathrm{CP}$ の症例を 対象としたがやはり左右何れからの刺激に対 
しても有意差を認め得なかった。しかし減衰係 数は正常群に比し小さい傾向を示した，中枢障 害群では症例によっては一側のみしか検査を実 施できなかったが（その理由は患者が年配であ り, 疲労を訴えたためである.) 一見して前二者 に比べて 減衰係数が低いことがわかる，症例 20，21の様に広範囲にわたって脳が障害を受け ている症例では, 特に減衰係数が著しく低值を 示した。また中枢障害群でも前二者と同様に左

\section{考}

現在通常に行われている平衡常用検査の中で 人体の摇れを検査する方法としてはロンベルグ 姿勢やマン姿勢に扣ける人体の安定度を調べる 検査法が行われているが，必ずしも客観的とは いいがたい、しかし，時田ら ${ }^{5)}$ は人が動的平衡 を保ちながら安定に起立姿勢を保持できるのは, 生体には頭部，体幹を絶えず重力に対して正し い位置に立ち直らせる反射（立ち直り反射, rigting reflex）があるためであり，この立ち 直り反射機構は視器, 迷路, 自己受容器, 外受 容器からの入力刺激を大脳あるいは脳幹を介し て小脳の統御を受けて行われる反射であるの で, 直立時の身体動摇の観察は視器, 迷路, 自 己受容器あるいは中枢神経系の障害で現れる立 ち直り反射障害把握のために最も重要な検査で あると述べている，その点で重心動摇検査法は 直立時の平衡機能障害を客観的に 評価する上 で，簡便かつ人体動摇を直接的に表現できる検 査法として評価できる。重心動摇計にお怙ける人 体動摇の解析は今日迄に種々の方法が報告され ている. その一つとして動摇面積を用いる方法 をみると多くの研究がなされていて，たとえば 松永 ${ }^{7)}$ は正常群と疾患群との間に差異が認めら れると報告した。身体の動摇の程度や動摇の質 の差を表现するためには, 重心動摇の軌跡距 離, ベクトルなどと並んで重心動摇面積の計測 は確かに有利な方法であろうと期待される.

また周波数分析についても種々の検討が加え られているが20) 24) 26) 29) 31) 33) 36) 39) -41), 臨床検
右からの刺激に対しては有意差を認めなかった. 減衰係数（Mean 95\% CL）は正常群 0.02168 \pm 0.00591 ，前庭障害群 $0.01182 \pm 0.00445$, 中 枢障害群 $0.00694 \pm 0.00205$ であった．前庭障 害群と正常群との間で有意差 $(\mathrm{p}<0.01)$ を認 め，また前庭障害群と中枢障害群との間にも有

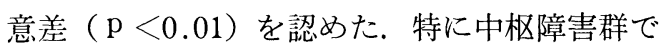
は前二者に比し非常に減衰係数が小さかった (図6).

\section{案}

査に応用するには，バラツキが大きくていまだ に一定の見解には到達していないのが実状であ る.

負荷を加える重心動摇の分析法としては, シ ーソー台によるもの ${ }^{25)}$, 振子様直線運動による もの42) などがあり身体動摇の周波数の差によ って視器, 迷路, 自己受容器の果たしている役 割も異なることなどが次第に明らかにされてい るが，やはり一般平衡外来での常用検查として 用いられるまでにはいたっていない。

今回著者らは重心動摇計を平衡外来に打いて 一般常用検査として取り入れるために，単に安 静起立時の重心動摇検査のみでは異常を示さな いよらな軽微な平衡障害者をも検出する事がで きるように負荷を与えた際のその立ち直り反射 時の重心動摇分析を試みたのである.

ローリング負荷および撃振による負荷とも に, 左右方向からの刺激のみを行ったのは, 人 体は左右に対象であるのに対して, 前後方向に は非対象であり, 三宅 ${ }^{23)}$ が前傾や後傾の状態に よってもその重心動摇には差異があると述べて いるように, 前後への負荷は分析するにはあま り適当でないと考光, 左右方向への負荷のみに ついて分析研究を行った.

また, 視性入力の重心動摇分析におよぼす影 響は大きく, 開眼時の動摇面積の減少や，軌跡 距離の減少などが報告されていて ${ }^{10) 15) 33134) 37) 43) ~}$ 46), 本実験では閉眼で検査を施行することとし た. 
実験 1 ）のローリング負荷では主に周波数の 遅い場合の立ち直り反射系について検討したわ けであるが，負荷 $0.15 \mathrm{~Hz}$ でパワー上限はほぼ 一定となった，中枢障害群では全体的にパワー 上限は高值を示し，これは臨床的にも中权障害 者の失調性の動摇と一致する。この中枢障害群 に括けるパワー上限の高值は, 正常群执よび前 庭障害群に比べて有意 $(\mathrm{p}<0.01)$ に大きいも のであった，前庭障害群では，正常群との差が 中枢障害群のそれに比べてあまり明瞭でなかっ た。これは時田らが迷路性立ち直り反射は動摇 の周期が早くなるほど大きな立り直り運動を誘 発する特性（微分制御動作）をもち迷路が早く 短い身体動摇に対する立ち直り運動の解発に大 きな役割をもつことを報告しているように，今 回の実験条件でのローリング負荷のように周波 数が低いと迷路性入力はあまり関係なくそのた め正常群と有意差がでなかったのであろう.

位相についても，正常者では負荷 $0.15 \mathrm{~Hz}$ 以 降で一定值となる傾向を示した．前庭障害群で は位相においても正常群との間に差異は少な く, 判別は困難である. 中枢障害群では特に負 荷周波数 $0.05 \mathrm{~Hz}$ で正常群および前庭障害群と の間に大きな有意差で重心移動の先行が大きい ことがわかった。

中枢障害群で位相のずれが大きいのは, 各種 の入力情報に基ずいて出力される運動系の調節 機構である小脳や脳幹の制御機能の障害によっ て，ローリング負荷に対する反応に『ずれ』が 生ずるためと解される.

実験 2 ）の撃振による負荷では正常群, 前庭 障害群, 中枢障害群ともに左右それぞれよりの 刺激に対して有意な差は認めなかった。しかし 正常群に执いて左側より刺激した場合に減衰係 数が高い印象があるが，その理由は分からな い。これはその人個人個人の効き足と関係があ るのかもしれない.

図 5 に示すように刺激後の 10 秒間の重心動摇 波形をプロットとしてみると 3 群に明らかに立 ち直りの違いが認められる. 正常群では刺激に
対して反対側へ大きく重心の移動が起こるがそ の後の立ち直りはシャープであって安定位に もどるさいに正中を越えることをかりに over shoot と呼ぶならば over shoot はほとんど見 られない，前庭障害群では正常群に比し大きく なり，中枢障害群ではより大きくて刺激に対し て安定位にもどるための抑制能力が弱い，つま り減衰能力が著しく弱いことが示された.

減衰係数では, 正常群, 前庭障害群, 中枢障 害群にそれぞれ危険率 $1 \%$ で有意差を認めた。 ローリング負荷では有意差を認めなかった正常 群と前庭障害群との群間にも有意差を認め得た のは，撃振による負荷で誘発される身体動摇の 周期では $0.5 \sim 0.8 \mathrm{~Hz}$ の周波数帯が主体であ るため先に述べた迷路性立ち直り反射が介入し ているためと解される，中枢障害群で減衰係数 が著しく低いのは，ローリング負荷刺激での結 果と同様に，各種の入力は入ってはくるものの それを総合して身体へ出力するべき中枢神経系 に障害があるためと考えられる.

今回の実験では刺激を加えた際のそれへの応 答としての身体の安定維持について検討を行っ た訳であるが，身体の安定維持には入出力系の 中心である小脳，脳幹が重要な役割を果たして いることを示唆する結果と考える，入力系とし ては, 迷路性, 視覚, 抗重筋伸張反射, 自己受容 器, (脊髄の弯曲やその他の関節受容器, 足蹠圧 受容体）等が考えられているが，本実験では閉 眼で，かつ左右方向の刺激を行ったため視覚よ りの入力はなく，また関節での姿勢調節は前後 方向よりの刺激に比べ少ないと考えている. 大 久保らは ${ }^{47)}$ 彼らの Shot gun-ball を敷き詰めた 板を用いた実験結果から足蹠 mechanoreceptor は等紡錘反射の脊骨迶レベルより上位の調節 系に情報を伝えていると述べている．このこと から考えると, 直立安定時に左右から刺激を受 けた場合にはゆっくりとした例えば船の摇れな どのような刺激時には主として足蹠圧受容体か らの入力を, また $0.5 \mathrm{~Hz}$ 以上の早い周波数成分 を持った例えば電車の急停止時などの場合はそ 
れに迷路性の入力が介入してその情報を中枢神 経系に伝え主に小脸，脳幹が姿勢を統御してい ると考兄られる。

終わりに本法の臨床的利用価值について考兄 るとローリング負荷では正常群および前庭障害 群との 差異が最も明瞭である 負荷周波数 0.05 $\mathrm{Hz}$ でパワー上限 $5.80 \mathrm{~Hz}$ 以上のものを中枢障 害群と判定すると78\%の確率で，また位相差十 $1957 \mathrm{msec}$ 以上を中枢障害群とすると $90 \%$ の確 率で判定可能である。
更に撃振による負荷刺激では減衰係数が 0.15 以上を正常群とするならば87\%の確率で，0.01 〜0.15の間を前庭障害群とするなら $67 \%$ の確率 で，0.01以下を中枢障害群とすると $86 \%$ の確率 で判定可能である.これは他の平衡学的検査法 と比較しても遜色はなく，患者に与兄る負担も 少なく，さらに手技の容易さを考慮すると一つ のめまい臨床検查として有用な検查法であると 考える.

\section{ま と め}

閉眼直立姿勢の被検者にローリング及び撃振による左右方向の刺激を行い検討を行った.

1) ローリング負荷

1. 前庭障害群では, 重心動摇の周波数分析に打ける構成成分パワーの上限, および相互相関分 析に括ける位相差には正常群との間に差異を認めなかった。

2. 中枢障害群では，負荷 $0.05 \mathrm{~Hz}$ でパワー上限が有意に高く，また位相差においても有意に 重心動摇が先行する度合が大きいことによって正常群および前庭障害群と区別された。

3. 特に中枢障害群と前庭障害群との判別を目的とする場合は負荷 $0.05 \mathrm{~Hz}$ 検査を行えばよく, 本判定法は患者に負担の少ない簡便な検査であることを示した.

2 ）撃振による負荷

1. 刺激後の重心動摇波形において前庭障害群は正常群に比し over shoot が大きく中枢障害群 では特に著しかった。

2. 左右それぞれの方向からの刺激に対して，その重心動摇の応答の減衰係数には特に有意差は 認めなかった。

3，減衰係数を計測すると，正常群と前庭障害群，前庭障害群と中枢障害群との間にそれぞれ 1 \%の危険率で有意差を認め，患者に与える負担が少なくまた手技が容易なことを考えると有効な検 查法であることを述べた.

本研究の一部は，第 $43 ， 44$ 回日本平衡神経学会，第 1，2 回文部省総合研究『平衡機能検査法』班会議にて口 演発表した.

\section{参 考 文 献}

1) 宮崎元滋: 小脳变性症患者の歩行, 足吒打静止時 重心動摇の記録と解析. 臨床神経 $20: 209 \sim 213$ 1980.

2 ) 白石君男, 調 重昭: 身体重心動摇定量の試又. 福大医紀 3: 145 150, 1976.

3 ) 田口喜一郎 : メニエール病の起立時重心動摇. 耳 鼻臨床 73: 1109 1117, 1976.
4 ）田口喜一郎, 依田美千恵 : 重心動摇分析法一重心 動摇領野と重心動摇軌跡距離一。 日耳鼻 79 : 1577 1589, 1976.

5 ) 時田 喬, 早野洋司, 田口拓雄, 島田六郎 : 頭部 並びに重心動摇記録計による立ち直り反射検査.

耳鼻臨床 65：443 456, 1972.

6) 大久保仁，渡辺 勈，小高修司，堤内邦彦，村瀬 
弘, 他 : 神経疾患に打ける平衡維持機構と重心動 摇一脊葡小脳变性症の足蹠受容体が身体動摇に及 ぼす影響について一. Equilibrium Res $38: 207$ 〜215, 1979.

7 ) 松永 喬, 奥村新一, 井奥国彦: 平衡機能検查一 の緊張性振動反射の応用. 臨床脳波 15: 336 374, 1973.

8 ) 室賀辰夫, 小長谷正明, 足立皓岑, 祖父江逸郎 : 脊髄小脳変性症の 重心動摇. 臨床神経 $20: 165$ $\sim 171,1980$.

9 ）斎藤一郎, 吉川幸宏 : 起立時の重心移動の定量化 (安定指数について). 医実報告 $14: 1 \sim 6,1973$.

10）武谷力：重心計を用いた人体の身体動摇に関す る研究. 耳鼻と臨床 $22: 608 \sim 621,1976$.

11）月村泰治, 山下八重子 : 重心図から見た脳性麻疾 の治療. 整形外科 $29: 227 \sim 234,1978$.

12) Seidel H and Brauer D: Effects of visual in. formation. Concious control and low-frequency whole body vibration on postural sway. Agressologie 20: 180 190, 1979.

13) Suga $H$ and Takemori $T$ : Measurement of body movement and its clinical application. JJ physiol 20 : 296 308, 1970.

14) Takeya $T: A$ biofeed back study of postural sway. Folia Phychi Neuro Japonica 30: 495 504, 1976.

15）川野六郎, 徳増厚二, 竹内義夫 : 重心動摇に対す る視覚系の抑制. Equilibrium Res 37 : 118〜 122, 1978.

16）松岡豊彦, 不破成和: 起立時身体動摇の定量的解 析一正常者について. J Transport Med 32: 83 $\sim 93,1978$.

17）坂口 明, 角田興一: 重心移動による平衡機能の 評価. 体力科学 26 : 64 69, 1977.

18）田口喜一郎：重心動摇の正常範囲について. 耳喉 46 : 415 420, 1979.

19）山本高司：直立時重心摇の年令による変化. 体力 科学 28: 249 256, 1979.

20) Wall IIIC and Black FO: Postural stability and rotational test; their effectiveness for screening dizzy patients. Acta Otolaryngol 95 : 235 246, 1983.

21）千綿国彦：ヒトの摇れから見た起立姿勢. 脳波と 筋電困 $4: 142 \sim 147,1976$.
22）小町清彦: 外耳道冷水刺激の閉眼直立姿勢に及ぼ す影響に関する研究. 名市大医誌 28：1345～ 1358, 1978.

23）三宅彰英 : 立位姿勢の保持及び運動時における体 重心位置と下肢筋の活動について. JJ Aerospace Environ Med 18: 1 9, 1981.

24）三好豊二, 白土 勝, 樋渡章二 : 身体動摇方向の 相関. Equilibrium Res 37 : 107 112, 1978.

25）水野義雄, 林 良一, 三宅章英, 渡辺 悟, 時々 輪浩穏，他：シーソ台上での姿勢の調節と身体動 摇. JJ Aerospace Environ Med 18: 10 20, 1981.

26）西村 充：起立姿勢における身体動摇に関する研 純一加速度記録図波の 臨床応用一。 日耳鼻 71 ： 1847 1893, 1977.

27）大久保仁, 渡辺 勈, 奥 常幸, 小高修司, 堤内 邦彦, 他 : 平衡調節障害に見られる重心動摇速度 power spectrum 分析の意義. Equilibrium Res $41: 83 \sim 89,1980$.

28）羽柴基之, 向井 研, 三宅彰英, 林 良一, 渡辺 悟: 人の立位重心動摇のパワースペクトラムの定 常性についての検討. Equilibrium Res 41:83 $\sim 89,1982$.

29）島田六郎：中枢性めまい平衡障害例の起立時身体 動摇の研究. 耳鼻臨床 $70: 1113 \sim 1190,1977$.

30）田口喜一郎, 飯島美千恵, 滝沢正臣 : 重心動摇の 周波数分析一周波数スペクトラムと平均周波数一。 耳鼻臨床 70: 825 831, 1977.

31）時田 喬：起立姿勢維持におおる迷路の働き一迷 路性筋緊張の検討一. 神経進歩 18：728〜737, 1974.

32）時田 喬, 宮田英男, 永田隆郎, 藤垣 熙, 小林 武, 他 : 直立時の身体動摇の分析一動摇の多現象 記録と相関分析による一。耳鼻臨床 63: 363〜 387, 1970.

33）渡辺 悟: 重心動摇からみた姿勢調節 Equilibrium Res 40 : 286 294, 1984.

34）米田 敏, 徳増厚二 : 正常人の直立時重心動摇の 周波数分析. Equilibrium Res 41 : 55 60, 1982.

35) Black FO and Wall IIIC: Comparison of vestibulooccular and vestibulispinal screening test. Otolaryngol Head Neck Surg 89: 811 817, 1981.

36) Koles ZT and Casttelein RD: The relations- 
hip between body sway and foot pressure in normal man. J Medic Engin Technol 4: $228 \sim 238,1981$.

37) Lestienne F, Soechting J and Berthoz A: Postural readjustments induced by linear motion of visual scene. Exp Brain Res 28: 363 384, 1977.

38）時田 喬, 前田正徳, 大橋伸一, 宮田英雄, 正木 道, 他: 迷路性立ち直り反射の動特性. Equilibrium Res 83:23〜28, 1979.

39）松岡豊彦：起立時身体動摇の定量的解析一正常者 について一. 交通医学 $32: 2 ； 27 \sim 36,1978$.

40）田口喜一郎：重心動摇周波数分析スペクトルの臨 床的応用. Equilibrium Res 37：113 117, 1978.

41) Cernacek J : Stabilography in Neurology. Agressologie 21D : 25 29, 1980.

42）藤原宏二：振子様直線運動刺激に対する姿勢反応 に関する研究. 耳鼻臨床 77: 171〜195, 1984.

43）三好豊二 : 視機刺激の重心動摇に及ぼす影響一重
心偏位の 2 相性について一. 耳鼻臨床 $61: 66$ 85, 1968.

44）田口喜一郎：メニエール病患者の重心動摇におよ ぼす視運動刺激の影響. 耳鼻臨床 73: 1879〜 1892, 1980.

45）田口喜一郎：視運動刺激の重心動摇に及ぼす影響。 耳鼻 $26:$ 182 191, 1980.

46) Ganthev GN, Dunev S and Draganova N : Infuluence of the visual feedback for some paramethers of the body oscillations on their stability. Acta Physiol Pharmacol Bulg $7: 13 \sim$ $18,1981$.

47）大久保仁, 渡辺 勈, Baron JB：足蹠圧受容体 が重心動摇に及ぼす影響について。耳鼻臨床 72 : 1553 1562, 1979.

/別刷請求先 : 森 裕司 干663 兵庫県西宮市武厙川町1-1 兵車医科大学耳鼻咽喉科学教室 